\section{UDC 519.865}

\section{S.V. Melnikov}

Odessa national maritime university

\section{PRICE COMPETITION BETWEEN RETAILERS}

UNDER SYMMETRIC COSTS

Integrating operations and marketing decisions are an important objective for retailers in today's competitive environment. An obvious problem common to the retail industry is the joint optimization of the lot size of a product to be stocked and the selling price in order to maximize profit. Pricing and inventory control strategies are closely related. Pricing decisions alter demand forecasts, which are used by inventory control systems. We note that in the classical economic order quantity (EOQ) model the demand is assumed as constant. A lot of important results have been obtained in this field of study. There are many studies which modify this condition, in particular with linear demand function. Further studies are related to the complexity of market structures, in particular, considering the horizontal competition between retailers.

In this paper the Bertrand's price competition in the retail duopoly with symmetric costs is analyzed. Retailers sell substitute products in the framework of the classical EOQ model with linear demand function. Products are stored in a warehouse and are evenly sold in the retail network. We assume that every retailer maximizes profit per unit of time on the order size and the price at a current price competitor. The market potential is considered to be the bifurcation parameter of retailers. Level of the barrier to market penetration depending on the bifurcation parameter is analyzed. The conditions of Bertrand-Nash equilibrium in parametric and trigonometric forms are found. The theoretical results are illustrated by a numerical example. Based on the results obtained, retailers can plan the level of profitability of logistics costs and assess the level of the entry barrier to the market.

(C) Melnikov S.V., 2017
Keywords: EOQ model, retail duopoly model, Bertrand-Nash equilibrium, market potential, bifurcation parameter, return on logistics costs, barrier to entry.

\section{Мельников С.B.}

\section{ЦІНОВА КОНКУРЕНЦІЯ МІЖ РІТЕЙЛЕРАМИ} ПРИ СИМЕТРИЧНИХ ВИТРАТАХ

Одеський національний морський університет

У даній роботі аналізується иінова конкурениія за Бертраном у моделі дуополії рітейлерів в умовах симетрї витрат. Рітейлери продають взаємозамінні продукти в умовах класичної EOQ моделі за лінійної функиії попиту. Потенціал ринку розглянуто в якості біфуркаиійного параметра рітейлерів. Проаналізовано рівень бар'єру входу на ринок у залежності від пара-метра біфуркащії. Знайдено умови стану рівноваги за Бертраном-Нешем в параметричній та тригонометричній формах.

Ключові слова: $E O Q$ модель, модель дуополї рітейлерів, рівновага Бертрана-Неша, потениіал ринку, біфуркачійний параметр, рентабельність логістичних витрат, бар'єр входу.

\section{Мельников С.В.}

\section{ЦЕНОВАЯ КОНКУРЕНЦИЯ МЕЖДУ РИТЕЙЛЕРАМИ} ПРИ СИММЕТРИЧНЫХ ЗАТРАТАХ

Одесский национальныгй морской университет

В данной работе анализируется ценовая конкуренция по Бертрану в модели дуополии ритейлеров при симметрии затрат. Ритейлеры продают взаимозаменяемые продукты в условиях классической EOQ модели при линейной функиии спроса. Потенциал рынка рассмотрен в качестве бифуркационного параметра ритейлеров. Проанализирован уровень барьера входа на рынок в зависимости от параметра бифуркации. Найдень 
условия состояния равновесия Бертрана-Нэша в параметрической и тригонометрической формах.

Ключевые слова: $E O Q$ модель, модель дуополии ритейлеров, равновесие Бертрана-Нэша, потенцииал рынка, бифуркационньй параметр, рентабельность логистических затрат, барьер входа.

Problem statement. Integrating operations and marketing decisions are an important objective for retailers in today's competitive environment. An obvious problem common to the retail industry is the joint optimization of the lot size of a product to be stocked and the selling price in order to maximize profit. Pricing and inventory control strategies are closely related. Pricing decisions alter demand forecasts, which are used by inventory control systems.

We note that in the classical economic order quantity (EOQ) model the demand is assumed as constant. A lot of important results have been obtained in this field of study. There are many studies which modify this condition [1], in particular with linear demand function $[2 ; 3]$. Further studies are related to the complexity of market structures, in particular, considering the horizontal competition between retailers [4]

In this article, we develop the obtained results herein [4] for model duopoly retailers with the Bertrand's price competition in the case of substitute products. Along with trigonometric solution, parametric solution is received as well, where the parameter is return on logistics costs. Parametric solution allows to determine the sufficient conditions for the existence of equilibrium with the symmetry retailers cost. The market potential is considered to be bifurcation parameters of retailers.

Recent research and publications analysis. Whitin [5] was the first researcher who indicated the fundamental connection between price theory and inventory control. He extended the basic EOQ model by considering the selling price in addition to the order quantity as the decision variables.
Optimization solutions for pricing and inventory management for the retailer's monopoly are represented in the works [2; 6-10].

The paper of Abad [2] is concerned with finding the optimal price and lot size for a retailer purchasing a product for which the supplier offers all-unit quantity discounts. Demand for the product is assumed to be a decreasing function of price, and a procedure is developed for finding the optimal price and lot size for a class of demand functions. Thomas [6] considers the problem of simultaneously making price and production decisions in dynamic for a single product with a known deterministic demand function. To maximise profit, an efficient algorithm is developed.

Kunreuther and Richard [7] have investigated the interrelationship between the pricing and inventory decisions for a retaile who orders his goods from an outside distributor. Smith et al. [8] have formulated and solved a single-item joint pricing and master planning optimization problem with capacity and inventory constrains.

Tripathi [9] develops an inventory model for deteriorating items with linearly time dependent demand rate under inflation and time discounting over a finite planning horizon. In paper [10] have analyzed the problem of determining the optimal price and lot size of retailer when demand is a linear function of price.

Study on retailers' competition in the vertical market conditions is presented in [11-16].

Sinha and Sarmah [11] have analyzed the coordination and competition issues in a two-stage supply-chain distribution system where two vendors compete to sell differentiated products through a common retailer in the same market. Huang et al. [12] analyze the coordination of enterprise decisions such as supplier and component selection, pricing and inventory in a three-level supply chain composed of multiple suppliers, a single manufacturer and multiple retailers. The problem is modelled as a dynamic non-cooperative game. 
Feng and $\mathrm{Lu}$ [13] have analyzed the contracting behaviors in a two-tier supply chain system consisting of two competing manufacturers selling to two competing retailers. Alaei et al. [14] have analyzed production - inventory decisions in a decentralized supply chain. A production inventory problem is considered in a two-leve supply chain. Modak et al. [15] have explored channel coordination and profit distribution in a two-layer socially responsible supply chain that consists of a manufacturer and two competitive retailers. In paper [16] the logistical system of manufacture and delivery of production on the consumer market, including suppliers, the manufacturer and the transport enterprises is considered. The paper [17] presents the effects arising at horizontal merger of firms, operating under conditions of the vertical market.

Study on retailers' competition in the horizontal market conditions is presented in $[4 ; 18 ; 19]$.

Otake and Min [4] have analyzed inventory and pricing policies for a duopoly of substitute products. Min [18] has extended the profit maximizing EOQ model to the case of a symmetric oligopoly consisting of sellers of a homogeneous product who complete with each other for the same potential buyers. Sadjadi and Fathollah Bayati [19] develop generalized network data environment analysis models to examine the efficiency of two-tier suppliers under cooperative and non-cooperative strategies where each tier has its own inputs/outputs and some outputs of the first tier can be fed back to the second tier.

The goal of this article is the optimization of price-inventory decisions of retailers in duopoly model under symmetric costs.

The basic results and their justification. Two retailers periodically buy the finished product from a wholesaler. Products are stored in a warehouse and are evenly sold in the retail network. We assume that every retailer maximizes profit per unit of time on the order size and the price at a current price competitor.

Linear demand function of $i$-th retailer (1)

$$
D_{i}=b-k \cdot p_{i}+\gamma \cdot\left(p_{j}-p_{i}\right),
$$

where $D_{i}$ - product demand of $i$-th retailer per unit time, $i=1,2$;

$p_{i}$ - price of product of $i$-th retailer per unit;

$p_{j}$ - unit price of $i$-th retailer's competitor product, $j=3-i$;

$b$ - market potential (maximal demand) per unit time;

$k>0$ - the own price effect;

$\gamma>0$ - the cross price effect.

From condition $0<D_{i}<b$ we obtain the range of acceptable prices $p_{i}<\frac{b+\gamma \cdot p_{j}}{k+\gamma}, p_{i}<\frac{p_{j} \cdot(k+\gamma)}{\gamma}$ (Figure 1$)$.

Note that in paper [4] the demand function was used in the form $D_{i}=b-k \cdot p_{i}+\gamma \cdot p_{j}$. In our opinion, this function has a disadvantage - at any ratio between prices, the final demand of $i$-th retailer is always higher than the base demand: $D_{i}>b-k \cdot p_{i}$. The increase in the basic demand of $i$-th retailer is due to the influx of new consumers from the competitor at $p_{i}<p_{j}$. Obviously, with $p_{i}>p_{j}$, the basic demand of $i$-th retailer should not increase, but decrease. Therefore, it is necessary to take into account the relationship between prices, as in (1).

Variables and parameters should be defined as follows:

$Q_{i}$ - the order size of $i$-th retailer;

$d_{i}=d_{\mathrm{j}}=d-$ the ordering cost of retailers;

$w_{i}=w_{j}=w-$ the variable cost per unit time of retailers;

$l_{i}=l_{j}=l-$ the holding cost per unit per unit time of retailers. 


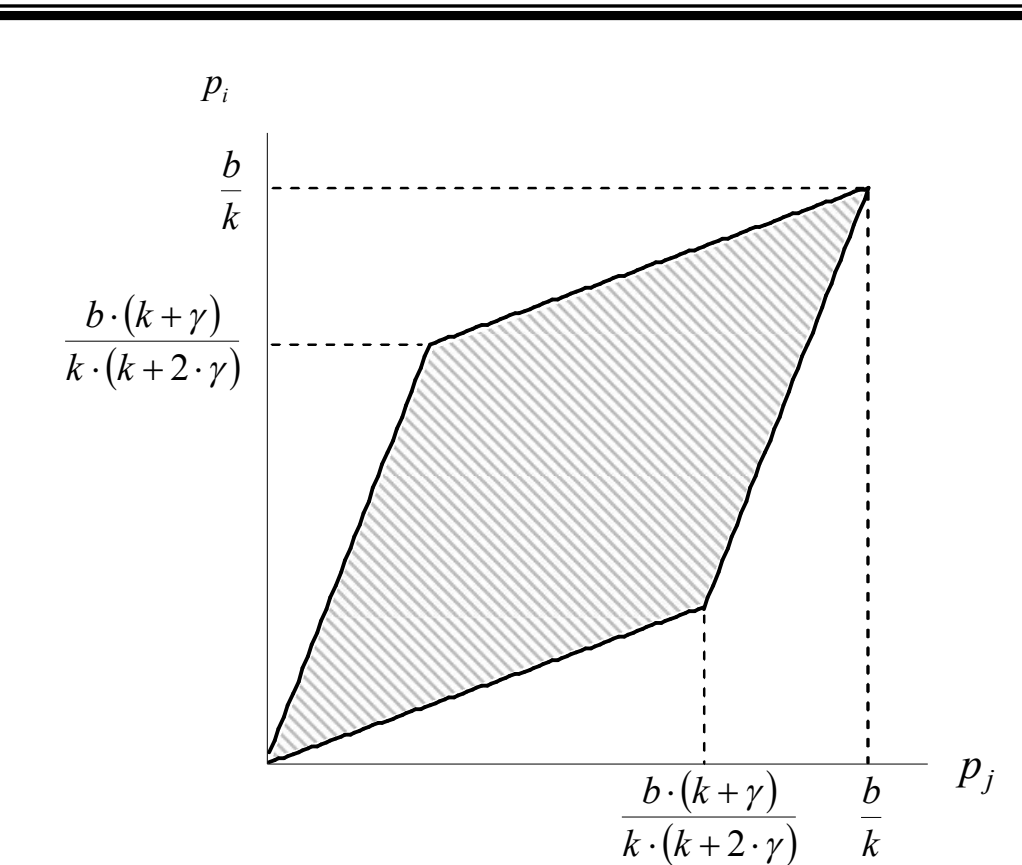

Fig. 1. The range of acceptable prices

The basic assumptions for traditional EOQ model applied in this article are the following:

- buyer's demand does not change;

- unlimited supply volume;

- no shortage;

- instant delivery.

With reference to the above mentioned, the price competition between retailers on the Bertrand model is analyzed. The objective function of $i$-th retailer (2)

$$
F_{i}=G P_{i}-L C_{i}=\left(p_{i}-w\right) \cdot D_{i}-\frac{d \cdot D_{i}}{Q_{i}}-\frac{Q_{i} \cdot l}{2} \rightarrow \max _{p_{i}, Q_{i}} .
$$

where $G P_{i}=\left(p_{i}-w\right) \cdot D_{i} \quad-$ gross profit per unit time, $L C_{i}=\frac{d \cdot D_{i}}{Q_{i}}+\frac{Q_{i} \cdot l}{2}-$ logistics costs per unit time.

The first-order necessary conditions (3)-(6):

$$
\begin{gathered}
\frac{\partial F_{i}}{\partial p_{i}}=b+\gamma \cdot p_{j}+w \cdot(k+\gamma)+\frac{d \cdot(k+\gamma)}{Q_{i}}-2 \cdot p_{i} \cdot(k+\gamma)=0, \\
\frac{\partial F_{i}}{\partial Q_{i}}=\frac{d \cdot D_{i}}{Q_{i}^{2}}-\frac{l}{2}=0
\end{gathered}
$$

or

$$
\begin{gathered}
p_{i}=\frac{\mathrm{w}}{2}+\frac{b+\gamma \cdot p_{j}}{2 \cdot(k+\gamma)}+\frac{d}{2 \cdot Q_{i}}, \\
Q_{\mathrm{i}}^{2}=\frac{2 \cdot d \cdot\left(b-k \cdot p_{i}+\gamma \cdot\left(p_{j}-p_{i}\right)\right)}{l} .
\end{gathered}
$$

Substituting (6) into (5), we obtain the reaction curves of $i$-th retailer, $R_{i}\left(p_{j}\right)$ in implicit form (7)

$$
p_{i}=\frac{\mathrm{W}}{2}+\frac{b+\gamma \cdot p_{j}}{2 \cdot(k+\gamma)} \pm \sqrt{\frac{d \cdot l}{8 \cdot\left(b-k \cdot p_{i}+\gamma \cdot\left(p_{j}-p_{i}\right)\right)}} .
$$

Under the assumption of symmetric costs, it can be easily verified that there exists an equilibrium point when $p_{i}^{e}=p_{j}^{e}, Q_{i}^{e}=Q_{j}^{e}$. Thus, at the equilibrium point, the formulas (5), (6) will be in the form

$$
p_{i}^{e}=\frac{b+(k+\gamma) \cdot\left(w+d / Q_{i}^{e}\right)}{2 \cdot k+\gamma}
$$




$$
Q_{i}^{e}=\sqrt{\frac{2 \cdot d \cdot\left(b-k \cdot p_{\mathrm{i}}^{\mathrm{e}}\right)}{l}} .
$$

To find the stationary points, we substitute (8) into (9) and equate to zero (10)

$$
Q_{\mathrm{i}}^{3}-\frac{2 \cdot d \cdot(k+\gamma) \cdot(b-k \cdot w)}{l \cdot(2 \cdot k+\gamma)} \cdot Q_{i}+\frac{2 \cdot d^{2} \cdot k \cdot(k+\gamma)}{l \cdot(2 \cdot k+\gamma)}=0
$$

We have obtained a cubic equation in reduced form. Thus, depending on the parameter values, the number of real stationary points can be 1,2 or 3 .

It should be noted that the key parameter for retailers is a market potential. It is interesting to analyze the dependence of the number of real stationary points of the market potential. For this, the market potential can be presented in the formula (10) as (11)

$$
b\left(Q_{i}\right)=k \cdot w+\frac{k \cdot d}{Q_{i}}+\frac{l \cdot(2 \cdot \mathrm{k}+\gamma)}{2 \cdot d \cdot(k+\gamma)} \cdot Q_{i}^{2} .
$$

The graph of the function $b\left(Q_{i}\right)$ is shown in Figure 2. Figure 2 shows that the number of real roots of the cubic equation (10) depends on the level of market potential. When $b<b_{i}^{b i f}$ the equation (10) has one real negative root $q_{3}$, when $b=b_{i}^{b i f}$ - one real negative root $q_{3}$ and one real positive two-fold root $q_{i}^{\text {bif }}$, when $b>b_{i}^{\text {bif }}-$ three real roots $\left(q_{1}>q_{2}>q_{3}\right)$. Thus, Figure 2 shows an imperfect pitchfork bifurcation, where the level of market potential is a bifurcation point [20]. Figure 2 also shows that the positive order size exists only when $b \geq b_{i}^{\text {bif }}$, so the bifurcation point can be considered as a barrier to entry for retailers.
It is easy to notice that the function $b\left(Q_{i}\right)$ at $Q_{i}=q_{i}^{b i f}$ has a local minimum. From the first order conditions (12)

$$
\frac{d b}{d Q_{i}}=\frac{2 \cdot l \cdot(2 \cdot k+\gamma) \cdot Q_{i}}{2 \cdot d \cdot(k+\gamma)}-\frac{\mathrm{k} \cdot d}{Q_{i}^{2}}=0
$$

we find

$$
Q_{\mathrm{i}}^{\mathrm{bif}}=\sqrt[3]{\frac{d^{2} \cdot k \cdot(k+\gamma)}{l \cdot(2 \cdot k+\gamma)}}
$$

Substituting (13) into (11), we find the bifurcation value of market potential of $i$-th retailer

$$
b_{\mathrm{i}}^{\mathrm{bif}}=k \cdot w+\sqrt[3]{\frac{27 \cdot d \cdot l \cdot k^{2} \cdot(2 \cdot k+\gamma)}{8 \cdot(k+\gamma)}}
$$

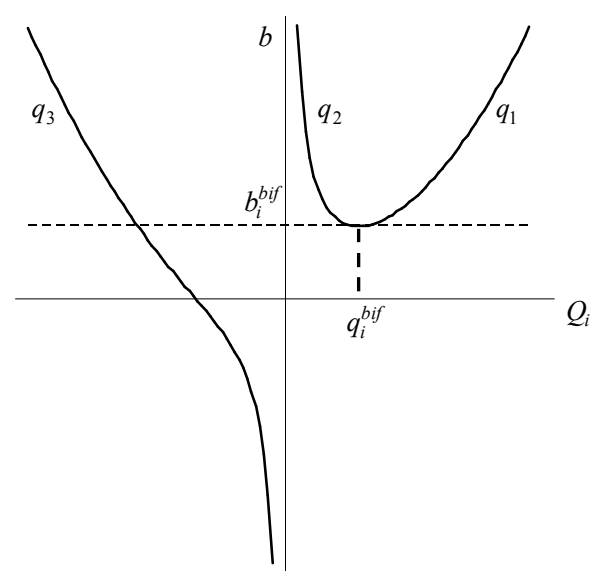

Fig. 2. Location of the real roots of equation (10) depending on the bifurcation parameter («imperfect pitchfork bifurcation» [20]) 
The parametric solution. Using $\left(b_{i}^{\text {bif }}, Q_{i}^{\text {bif }}\right)$, we define stationary points of $i$-th retailer in parametric form. Consider the functions

$$
b_{\mathrm{i}}^{\mathrm{h}}=k \cdot w+\sqrt[3]{h_{i}^{b} \cdot \frac{d \cdot l \cdot k^{2} \cdot(2 \cdot k+\gamma)}{k+\gamma}}
$$

and $\quad Q_{i}^{h}=\sqrt[3]{h_{i}^{Q} \cdot \frac{d^{2} \cdot k \cdot(k+\gamma)}{l \cdot(2 \cdot k+\gamma)}}, \quad$ where $\quad b_{i}^{h}, Q_{i}^{h} \quad-$ parametric representation of the roots of the equation (10), $h_{i}^{b}, h_{i}^{Q}-$ yet unknown parameters, $h_{i}^{b}=f\left(h_{i}^{Q}\right)$. Substituting $b_{i}^{h}$ and $Q_{i}^{h}$ into equation (10), determine the relationship between the parameters $h_{i}^{b}=\left(h_{i}^{Q}+2\right)^{3} /\left(8 \cdot h_{\mathrm{i}}^{\mathrm{Q}}\right)$. Let $h_{i}^{Q}=h_{i}$, then $h_{i}^{b}=\left(h_{i}+2\right)^{3} /\left(8 \cdot h_{i}\right), h_{i} \neq 0$. form (15)

Thus, the real roots of the equation (10) in the parametric

$$
\begin{gathered}
b_{\mathrm{i}}^{\mathrm{h}}=k \cdot w+\frac{h_{i}+2}{2} \cdot \sqrt[3]{\frac{d \cdot l \cdot k^{2} \cdot(2 \cdot k+\gamma)}{h_{i} \cdot(k+\gamma)}} \\
Q_{i}^{h}=\sqrt[3]{\frac{h_{i} \cdot d^{2} \cdot k \cdot(k+\gamma)}{l \cdot(2 \cdot k+\gamma)}}
\end{gathered}
$$

When the $h_{i}<0$ we obtain the root $q_{3}$, when $0<h_{i}<1-$ the root $q_{2}$, when the $h_{i}=1-$ bifurcation point $q_{i}^{\text {bif }}$, when $h_{i}>1-$ the root $q_{1}$ (Figure 2 ).

Substituting (15) into (5), we determine the price through the parameter (16)

$$
p_{i}^{h}=w+\left(\frac{k \cdot\left(h_{i}+2\right)}{2 \cdot(k+\gamma)}+1\right) \cdot \sqrt[3]{\frac{d \cdot l \cdot(k+\gamma)^{2}}{k \cdot h_{i} \cdot(2 \cdot k+\gamma)^{2}}}
$$

We can give an economic interpretation to the $h_{i}$-parameter. The $h_{i}$-parameter is expressed through a relative indicator of economic efficiency - return on logistics costs, which is given by: $r_{i}=\left(\mathrm{GP}_{\mathrm{i}}-L C_{i}\right) / \mathrm{LC}_{\mathrm{i}}$.

Substitute the parametric solution (15)-(16) into the original profit function (17)

$F_{\mathrm{i}}^{\mathrm{h}}=G P_{i}-L C_{i}=\frac{k \cdot\left(h_{i}+2\right)+2 \cdot(k+\gamma)}{4 \cdot(2 \cdot k+\gamma)} \cdot \sqrt[3]{\frac{h_{i} \cdot d^{2} \cdot l^{2} \cdot k \cdot(k+\gamma)}{2 \cdot k+\gamma}}-\sqrt[3]{\frac{h_{i} \cdot d^{2} \cdot l^{2} \cdot k \cdot(k+\gamma)}{2 \cdot k+\gamma}} .(17)$

From (17) we determine the return on logistics costs: $r_{\mathrm{i}}=\frac{k \cdot\left(h_{\mathrm{i}}-4\right)-2 \cdot \gamma}{4 \cdot(2 \cdot k+\gamma)}$, where the $h_{i}=\frac{(2 \cdot k+\gamma) \cdot\left(4 \cdot r_{i}+2\right)}{k}$.

Thus, the solution (15)-(16), where the parameter is return on logistics costs, is expressed as follows (18):

$$
\begin{gathered}
b_{i}^{r}=\mathrm{k} \cdot w+\left(k+(2 \cdot k+\gamma) \cdot\left(2 \cdot r_{i}+1\right)\right) \cdot \sqrt[3]{\frac{d \cdot l}{\left(4 \cdot r_{i}+2\right) \cdot(k+\gamma)}}, \\
Q_{i}^{r}=\sqrt[3]{\frac{d^{2} \cdot\left(4 \cdot r_{i}+2\right) \cdot(k+\gamma)}{l}} \\
p_{i}^{r}=w+2 \cdot\left(r_{i}+1\right) \cdot \sqrt[3]{\frac{d \cdot l}{\left(4 \cdot r_{i}+2\right) \cdot(k+\gamma)}}
\end{gathered}
$$

At the bifurcation point $\left(h_{i}=1\right)$ the return on logistics costs is equal: $r_{i}^{b i f}=-\frac{3 \cdot k+2 \cdot \gamma}{4 \cdot(2 \cdot k+\gamma)}$. Let us define the boundaries of changes in profitability, depending on the coefficients of price sensitivity of demand. Since $\gamma \in(0 ; k)$, then $r_{\mathrm{i}}^{\text {bif }} \in(-0,417 ;-0,375)$. When $h_{i}>1$, return on logistics costs will increase, so the retailers are interested only in the root $q_{1}$. 
Now it is necessary to analyze the extrema of the function (2). For this, we define the Hessian matrix (19)

$$
H_{i}=\left[\begin{array}{cc}
\frac{\partial^{2} F_{i}}{\partial p_{i}^{2}} & \frac{\partial^{2} F_{i}}{\partial p_{i} \partial Q_{i}} \\
\frac{\partial^{2} F_{i}}{\partial Q_{i} \partial p_{i}} & \frac{\partial^{2} F_{i}}{\partial Q_{i}^{2}}
\end{array}\right]=\left[\begin{array}{cc}
-2 \cdot(k+\gamma) & -\frac{d_{i} \cdot(k+\gamma)}{Q_{i}^{2}} \\
-\frac{d_{i} \cdot(k+\gamma)}{Q_{i}^{2}} & -\frac{2 \cdot d_{i} \cdot\left(b-k \cdot p_{i}+\gamma \cdot\left(p_{j}-p_{i}\right)\right)}{Q_{i}^{3}}
\end{array}\right]
$$

As it is known, the type of extrema of the function depends on the character of definiteness of the Hessian matrix evaluated at the stationary points. The character of definiteness of the Hessian matrix (19) depends on stationary points (18) and may be different. We are interested in the dependence of the indicator $r_{i}$. Since we need the maximum, we will find conditions under which the Hessian matrix is negative definite.

According to Sylvester's criterion the matrix (19) is negative definite when $\left|H_{i}\right|>0$ or

$$
4 \cdot Q_{i} \cdot\left(b-k \cdot p_{i}+\gamma \cdot\left(p_{j}-p_{i}\right)\right)-d \cdot(k+\gamma)>0 \text {. }
$$

Substituting the parametric solution (18) into the condition (20), we obtain a sufficient condition for a maximum: $r_{i}>-37,5 \%$. Thus, only root $q_{1}$ include the point of maximum of the function (2), $Q_{i}^{\mathrm{e}} \in q_{1}, Q_{i}^{e}>Q_{i}^{b i f}$

Thus, the condition for entering the market for retailers

$$
b>b(r=-0,375)=k \cdot w+(6 \cdot k+\gamma) \cdot \sqrt[3]{\frac{d \cdot l}{32 \cdot(k+\gamma)}} .
$$

The Bertrand-Nash equilibrium between retailers will be achieved at $r_{i}^{e}$ and $r_{j}^{e}$ ensuring equality of the potential: $b_{i}^{r}\left(r_{i}^{e}\right)=b_{j}^{r}\left(r_{j}^{e}\right)=b$ and at the point of intersection of the reaction curves: $R_{i}\left(p_{j}^{r}\left(r_{j}^{e}\right)\right)=R_{j}\left(p_{i}^{r}\left(r_{i}^{e}\right)\right), r_{i}^{e}=r_{j}^{e}$.

The trigonometric solution. Let us find the roots of the cubic equation (10) explicitly. Since the discriminant of the cubic equation (10) for $b>b_{i}^{\text {bif }}$ is negative, we will seek the trigonometric solution. Introduce the function (21)

$$
\varphi_{i}=\arccos \left(-\sqrt{\left(\frac{b_{i}^{b i f}-\mathrm{k} \cdot w}{b-k \cdot w}\right)^{3}}\right) .
$$

Then the roots of the cubic equation (10) are equal

$$
\begin{gathered}
\mathrm{z}_{i 1}=2 \cdot \sqrt{\frac{2 \cdot d \cdot(b-k \cdot w) \cdot(k+\gamma)}{3 \cdot l \cdot(2 \cdot k+\gamma)}} \cdot \cos \frac{\varphi_{i}}{3} ; \\
z_{i 2}=2 \cdot \sqrt{\frac{2 \cdot d \cdot(b-k \cdot w) \cdot(k+\gamma)}{3 \cdot l \cdot(2 \cdot k+\gamma)}} \cdot \cos \frac{\varphi_{i}-2 \cdot \pi}{3} ; \\
z_{i 3}=2 \cdot \sqrt{\frac{2 \cdot d \cdot(b-k \cdot w) \cdot(k+\gamma)}{3 \cdot l \cdot(2 \cdot k+\gamma)}} \cdot \cos \frac{\varphi_{i}+2 \cdot \pi}{3} .
\end{gathered}
$$

In the analysis of the sufficient conditions it has been found that the equilibrium order size belongs to the right-hand branch of the function $b\left(Q_{i}\right)$ (Figure 2): $Q_{i}^{\mathrm{e}} \in q_{1}=\max \left\{z_{i 1}, z_{i 2}, z_{i 3}\right\}$. Compare the roots of (22) with each other. For the $b>b_{i}^{b i f}$ the range of function (21) is equal: $\varphi_{i} \in(\pi / 2 ; \pi)$. For $\varphi_{i} \in(\pi / 2 ; \pi)$ the inequality $\cos \frac{\varphi_{i}}{3}>\cos \frac{\varphi_{i}-2 \cdot \pi}{3}>\cos \frac{\varphi_{i}+2 \cdot \pi}{3}$, therefore $q_{1}=z_{i 1}, \quad q_{2}=z_{i 2}$, $q_{3}=z_{i 3}$. The equilibrium order size: $Q_{i}^{\mathrm{e}} \in z_{i 1}$. 
Numerical example and sensitivity analisis. We illustrate the obtained results on the numerical example, using data from [4]. Data are presented in Table 1.

Table 1

Initial numerical example data

\begin{tabular}{|c|c|c|c|c|c|}
\hline$b$ & $k$ & $\gamma$ & $w$ & $l$ & $d$ \\
\hline 100 & 1,0 & 0,5 & 20 & 4,0 & 500 \\
\hline
\end{tabular}

The equilibrium variables are presented in Table 2.

Table 2

Equilibrium variables

\begin{tabular}{|c|c|c|c|c|c|c|c|}
\hline$p_{i}^{e}$ & $p_{j}^{e}$ & $Q_{i}^{e}$ & $Q_{j}^{e}$ & $F_{i}^{e}$ & $F_{j}^{e}$ & $r_{i}^{e}$ & $r_{j}^{e}$ \\
\hline 54,8 & 54,8 & 106 & 106 & 1148 & 1148 & 2,7 & 2,7 \\
\hline
\end{tabular}

Profit function of the $i$-th retailer at $\mathrm{p}_{j}=p_{j}^{e}$ is shown in Figure 3

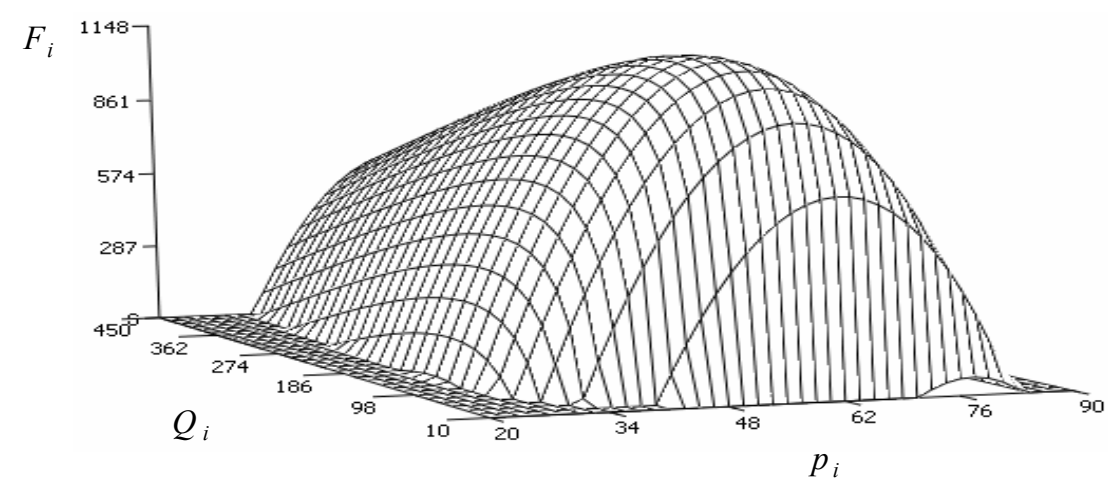

Fig. 3. Profit function of the $i$-th retailer
Now we study the impact of changes in the values of the key parameters $b, k, \gamma, w, d, l$ on the equilibrium profit of the $i$-th retailer. We change one parameter at a time, keeping the other parameters unchanged. The results are summarized in Table 3 (Figure 4).

Table 3

The impact of changes in the values of the key parameters on the equilibrium profit of the $i$-th retailer

$\begin{array}{ccccccc}\begin{array}{c}\% \\ \text { changes }\end{array} & b & \mathrm{k} & \gamma & w & d & l \\ -25 & 409 & 1859 & 1170 & 1334 & 1199 & 1199 \\ -20 & 531 & 1683 & 1166 & 1295 & 1188 & 1188 \\ -15 & 667 & 1527 & 1162 & 1258 & 1178 & 1178 \\ -10 & 815 & 1387 & 1157 & 1221 & 1168 & 1168 \\ -5 & 975 & 1261 & 1153 & 1184 & 1158 & 1158 \\ +5 & 1334 & 1046 & 1143 & 1112 & 1139 & 1139 \\ +10 & 1531 & 952 & 1139 & 1077 & 1130 & 1130 \\ +15 & 1742 & 868 & 1134 & 1043 & 1121 & 1121 \\ +20 & 1964 & 790 & 1129 & 1009 & 1112 & 1112 \\ +25 & 2199 & 719 & 1124 & 975 & 1103 & 1103\end{array}$

Based on the results of Table 3 , the following observation can be made.

1. A higher value of market potential $b$ results in higher values of equilibrium profit of the $i$-th retailer. Additionally, we find that equilibrium profit of the $i$-th retailer are highly sensitive to changes in $b$.

2. A higher value of other parameters $k, \gamma, \mathrm{w}, d, l$ results in lower values of equilibrium profit of the $i$-th retailer. Additionally, we find that equilibrium profit of the $i$-th retailer are highly sensitive to changes in $k$. 
Also we have got that ordering and holding costs equally influence on the equilibrium profit of the $i$-th retailer.

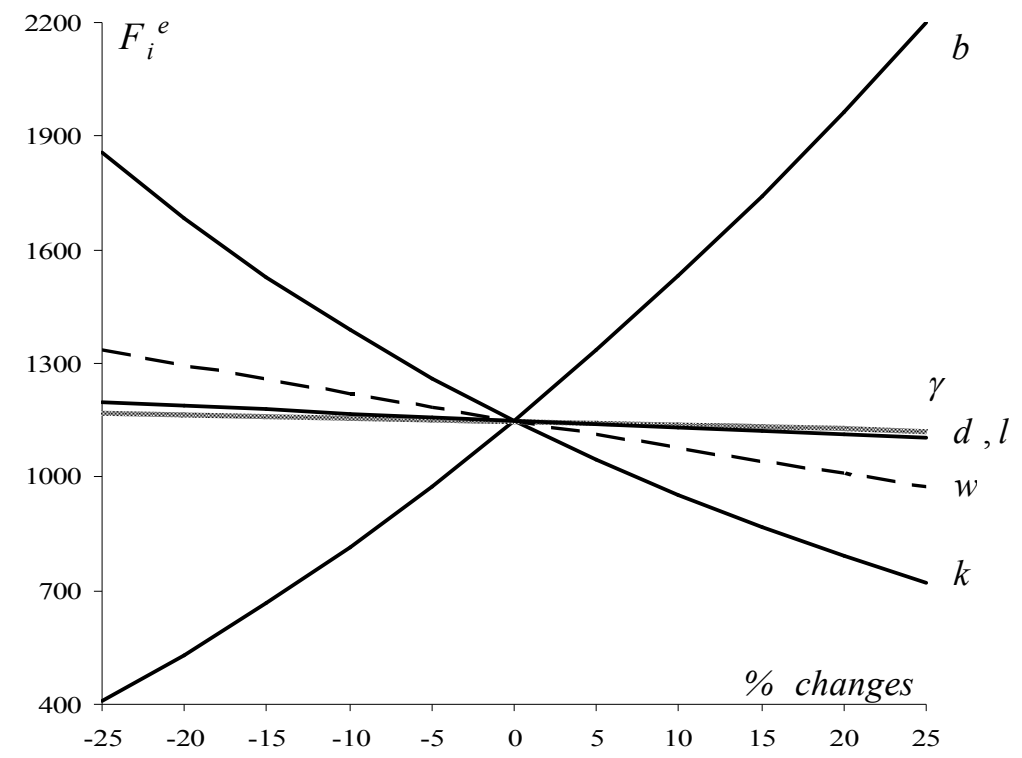

Fig. 4. Sensitivity analysis of equilibrium profit of the $i$-th retailer

Conclusions. In this article we have analyzed the price competition between retailers in duopoly model under symmetric costs. The market potential is considered to be the bifurcation parameter of retailers. The necessary and sufficient conditions for the existence of extrema are analyzed. The optimal solution in parametric form, where the parameter is the return on logistics costs, is found. The solution is determined in explicit form, taking into account the bifurcation point. The theoretical results are illustrated by a numerical example. Based on the results obtained, retailers can plan the level of profitability of logistics costs and assess the level of the entry barrier to the market.

\section{REFERENCES}

1. Chan L.M.A. Coordination of Pricing and Inventory Decisions: A Survey and Classifications / L.M.A. Chan, Z.J.M. Shen, D. Simchi-Levi, J.L. Swann // Handbook of Quantitative Supply Chain Analysis: Modelling in E-Business Era. - Springer-Verlag US. - 2004. - № 5. P. 335-392.

2. Abad P.L. Determining Optimal Selling Price and Lot Size when the Supplier offers All-Unit Quantity Discounts / P.L. Abad // Decision Sciences. - 1988. Vol. 19. - № 3. - P. 622-634.

3. Chen C.K. An Analysis of Optimal Inventory and Pricing Policies under Linear Demand / C.K. Chen, K.J. Min // Asia-Pacific Journal of Operational Research. - 1994. № 11. - P. 117-129.

4. Otake T. Inventory and Pricing Policies for a Duopoly of Substitute Products / T. Otake, K.J. Min // Proceedings of the Fifth Industrial Engineering Research Conference, Minneapolis, Minnesota. - 1996. - P. 293-298.

5. Whitin T.M. Inventory Control and Price Theory / T.M. Whitin // Management Science. - 1955. - № 2. P. 61-68.

6. Thomas J. Price-Production Decisions with Deterministic Demand / J. Thomas // Management Science. - 1970. - № 16. - P. 747-750.

7. Kunreuther H. Optimal Pricing and Inventory Decisions for Non-Seasonal Items / H. Kunreuther, J.F. Richard // Econometrica. - 1971. - Vol. 39. - № 1. - P. 173-175.

8. Smith N.R. Optimal Pricing and Production Master Planning in a Multiperiod Horizon Considering Capacity and Inventory Constraints / N.R. Smith, J.R. Limon, L.E. Cardenas-Barron // Mathematical Problems in Engineering. - 2009. 
9. Tripathi R.P. Economic Order Quantity for Deteriorating Items with Non Decreasing Demand and Shortages Under Inflation and Time Discounting / R.P. Tripathi // International Journal of Engineering, Ttransactions $C$ : Aspects. - 2015. - Vol. 28. - № 9. - P. 1295-1302.

10. Melnikov S.V. Optimal pricing and inventory decisions of retailer in EOQ model with linear demand / S.V. Melnikov // Development of administration and economic management methods on transport. - Odessa: ONMU, 2016. - Vol. 1 (54), - P. 21-43.

11. Sinha $S$. Coordination and price competition in a duopoly common retailer supply chain / S. Sinha, S.P. Sarmah // Computers \& Industrial Engineering. - 2010. - Vol. 59. - P. 280-295.

12. Huang Y. Coordinating Pricing and Inventory Decisions in a Multi-Level Supply Chain: A Game-Theoretic Approach / Y. Huang, G.Q. Huang, S.T. Newman // Transportation Research Part E: Logistics and Transportation Review. - 2011. - Vol. 47. - № 2. - P. 115-129.

13. Feng Q. Supply chain contracting under competition: Bilateral bargaining vs. Stackelberg / Q. Feng, L.X. Lu // Production and Operations Management. - 2013. Vol. 22. - № 3. - P. 661-675.

14. Alaei S. Analysis of Production - Inventory Decisions in a Decentralized Supply Chain / S. Alaei, M. Behravesh, N. Karegar // Prague Economics Papers. - 2014. № 2. - P. 198-216.

15. Modak N.M. Pricing policy and coordination for a twolayer supply chain of duopolistic retailers and socially responsible manufacturer / N.M. Modak, S. Panda, S.S. Sana // International Journal of Logistics Research and Applications. - Vol. 19. - № 6.
16. Мельников С.В. Синергетика логистической системы / С.В. Мельников // Методи та засоби управління розвитком транспортних систем: Зб. наук. працуь.Oдеса: OHMУ, 2008. - Bun.14. - C.149-162.

17. Melnikov S.V. Modeling the effects of horizontal firm mergers under conditions of vertical market / S.V. Melnikov // Actual Problems of Economics. - Vol. 4. № 118. - P. 250-255.

18. Min K. Inventory and pricing policies under competetion / K. Min // Operations Research Letters. - 1992. Vol. 12. - № 4. - P. 253-261.

19. Sadigh A.N. A Game Theoretic Approach to Coordination of Pricing, Advertising, and Inventory Decisions in a Competitive Supply Chain / A.N. Sadigh, S.K. Chaharsooghi, M. Sheikhmohammady // Journal of Industrial and Management Optimization. - 2016. - Vol. 12. - № 1. - P. 337-355.

20. Zhang W.-B. Synergetic Economics: Time and Change in Nonlinear Economics / W.-B. Zhang. - Berlin: SpringerVerlag, 1991.

Стаття надійшла до редакиії 15.05.2017

\section{Рецензенти:}

доктор економічних наук, старший науковий співробітник відділу ринку транспортних послуг Інституту проблем ринку та економіко-екологічних досліджень НАН

\section{України С.В. Ільченко}

доктор економічних наук, професор, завідувач кафедри «Менеджмент та маркетинг на морському транспорті» Одеського національного морського університету М.Я. Постан 